\title{
UK government slammed for Kew Gardens budget crunch
}

Parliamentary report urges stable funding for leading botanic garden hit by cash crisis.

\section{Richard Van Noorden}

04 March 2015

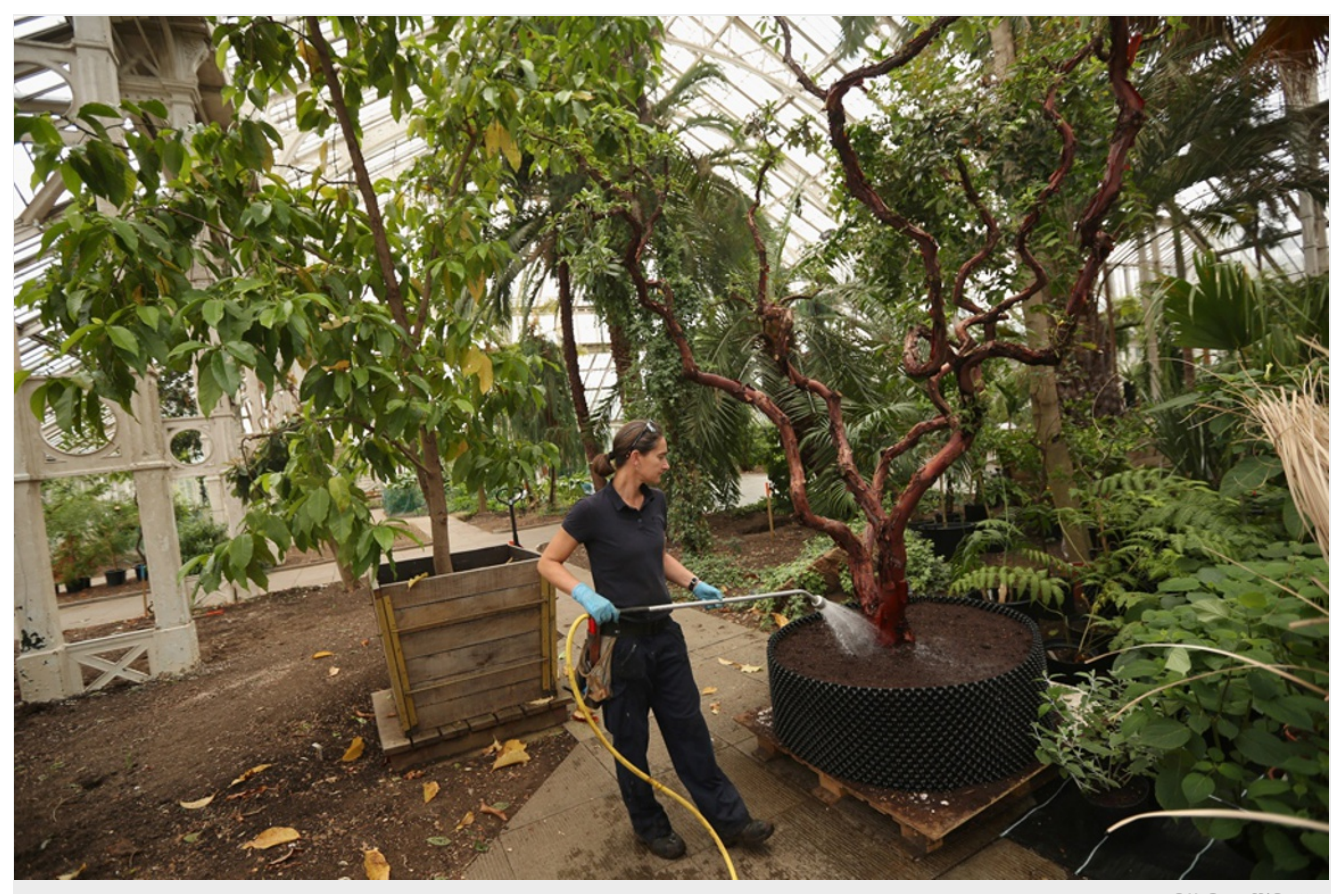

Oli Scarf/Getty

A 2014 budget shortfall forced the Royal Botanic Gardens, Kew, to lay off roughly one-fifth of its research staff.

A British parliamentary committee has castigated the UK government for failing to securely fund a world-leading plant-science centre in London, leading to a budget crisis and job losses that are undermining the centre's scientific work.

"We consider the current financial arrangements for funding to be a recipe for failure," concludes the report, published on 4 March. It lays much of the blame for the trouble at the Royal Botanic Gardens, Kew, on the Department for Food and Rural Affairs (DEFRA).

Last year, the centre laid off 47 full-time scientists — around one-fifth of its research staff — after suffering a £5.5-million (US\$8.4million) budget shortfall. Botanists around the world raised alarm during an inquiry held in December by the UK House of Commons Science and Technology Committee, warning that the cuts could damage the centre's work in plant and fungal taxonomy, its ability to maintain a seed bank to protect biodiversity, and its policy work to help prevent the illicit trading of endangered species.

"The government must work out a stable way of funding the gardens that provides greater long-term certainty for Kew's important work," says Andrew Miller, the chair of the committee. The centre should also be given more freedom over its budget, the report says; Kew currently must receive approval from DEFRA each year for many of its purchases. A spokesperson for DEFRA said the department would respond to the report shortly, but was already planning to give Kew more flexible funding next year.

"Kew needs long-term investment backed by government. This will ensure that we are able to adequately care for our collections, which are not only a priceless national asset but also an extraordinary global resource," a spokeperson for Kew said in response to the report.

\section{Growing need}

A team brought in to restructure science at the centre declares that its research remains strong. In February, Kew announced a new science strategy, including launching an annual report on the state of the world's plants and digitizing many of the centre's 7 million dried plant specimens. Kew's director of science Kathy Willis says that despite the job losses, she finds it hard to name things that Kew 
has actually had to cut back on — beyond being more selective in specimen collection, and cutting conservation biology programmes, such as planting trees to restore ecosystems.

But the physical state of the Royal Botanic Gardens — which is a UNESCO World Heritage Site — is deteriorating. The gardens house more than 19,000 species, including giant water lilies, towering pine trees and rare orchids, many in huge iron-framed greenhouses that need metalwork restoration and thousands of panes of glass replaced. "I don't yet have a plan to ensure how these buildings can be maintained for future generations," says Richard Deverell, the director of the gardens.

The centre, which has a total income of around $£ 60$ million per year, is trying to wean itself off government cash. DEFRA funding for Kew has declined from £28.6 million in 2009-10 to a projected £20.4 million in 2015-16 (which even includes an emergency boost of $£ 2.3$ million announced in December, just before the committee inquiry). Meanwhile, income generated from charging visitors, charitable donations, outside consultancy work and project grants is growing. "We have to focus on alternative fundraising," says Willis, noting that scientists at the centre secured five new research grants in the last month alone.

Morale among staff is recovering, says Deverell — even though many of the centre's workforce had to reapply for jobs after the restructure. Critical feedback from a staff survey last November marked the nadir, but was not as bad as he feared, he says: "You can't take out 47 full-time scientists without leaving some bruises."

Nature I doi:10.1038/nature.2015.17045 